\title{
The Application of Risk Matrix Method in Quality Evaluation of Wheat Flour
}

\author{
Haihong Xin'1, a, Yahui Wu1, ${ }^{1, b}$ Qian Zhang ${ }^{1, c}$, \\ Yuanyuan Zuo ${ }^{1, d}$ and Nan Zhang ${ }^{1, e}$ \\ ${ }^{1}$ College of Quality and Technical Supervision Hebei University Baoding $\quad 071000$, China \\ aXinhaihong498@163.com , b45695796@qq.com , \\ c1047680753@qq.com, ‘328131492@qq.com,e584990331@qq.com
}

Keywords: Flour; Risk matrix; Index; Quality and safety; Risk assessment

\begin{abstract}
In order to control the food safty risk about wheat flour effectively, this paper identify the quality and safety risk factors of wheat flour by collecting the country nearly five years of datas for the supervision and check, and combined with access to information of media exposure or consumer complaints of flour quality and safety problems. And then, establish the wheat flour quality evaluation index system, applying evaluation model of risk matrix to implementing the risk assessment for 19 indexes of wheat flour. Each risk index of wheat flour has its own food safety risk level. Different levels take different control measures, thus providing reference for effectively controlling the quality of the wheat flour safety risk.
\end{abstract}

\section{Introduction}

Flour is the basic raw material of food industry, its quality and safety problems not only involving the health problems of homes, but also affecting the health problems of downstream processing food enterprises. The national regulatory data from 2010 to 2014 indicates, the quality safety problems of whitening agent, formaldehyde and talcum powder frequently cropped up leads to market disorder. At the same time, it also increases the difficulty of government regulation. Flour has different degrees of uncertainty risk in production, processing and other aspects. The key to early warning risk and controlling food safety is to identify and evaluate flour safety hazard factors. Therefore, establishing a scientific and reasonable index system for quality safety evaluation of wheat flour is urgently for improving the quality level of wheat flour macroscopically.

\section{Research status of quality evaluation of wheat flour and Evaluation model selection}

Risk assessment criteria has been involved in the food safety regulation and developed corresponding standards in the Eleventh Five-Year. But owing tolate start, personnel shortage, inadequate capital investmentand a series of reasons, China's basis of risk assessment is weak. Some supportive research methods and seriously insufficient data causd the situation of food safety in China is difficult to break through. ${ }^{[1]}$ Recently, many scholars have made broad scale research from many angles in the aspect of food safety risk assessment, and applied risk analysis and evaluation tools to food industry, such as risk matrix method, fuzzy comprehensive evaluation method, hazard analysis and critical control, Bro-d order value method and so on. Despite progress has been made in the study of individual risk factors for wheat flour, the literatures about comprehensive analysis of wheat flour is lacking. Risk matrix method is a kind of risk evaluation index system which is established by the identification of risk, assess the probability of occurrence of risk and the degree of risk impact, and then determine the risk level. This method can be used toanalyze the risk factors in wheat flour in a multi-dimensional way.

In the risk matrix model, the function $\mathrm{Z}=\mathrm{F}(\mathrm{x}, \mathrm{y})$ represents the probability of occurrence of risk(x),risk impact degree (y), andthe relationship between risk grade (z).According to the theory of 
variance, the function expression of determining the relationship between $\mathrm{z}$ and $\mathrm{x}$, yis:

$$
\mathrm{Z}=\left(m x^{2}+n y^{2}\right) 1 / 2
$$

In the formula, $\mathrm{m}$ and $\mathrm{n}$ are probability coefficients, reflected respectivelythe contribution of $\mathrm{X}$ and $\mathrm{y}$ to $\mathrm{Z} .{ }^{[2]}$ Because wheat flour is the basic raw material of food, severity is more important thanpossibility for the risk grade, so take $\mathrm{m}=0.4, \mathrm{n}=0.6$.

Risk level zoning is shown in Table 1:the probability of occurrence of risk is abscissa, the influence degree of risk is ordinate. The zone is divided into high risk $(4,5]$, high risk $(3,4]$, medium $\operatorname{risk}(2,3]$, low risk [1,2] four grades.

\begin{tabular}{|c|c|c|c|c|c|}
\hline \multirow{6}{*}{ 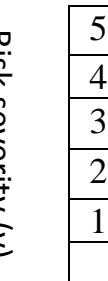 } & 4 & 4 & 4 & 4 & 5 \\
\hline & 3 & 3 & 3 & 4 & 4 \\
\hline & 2 & 2 & 3 & 3 & 3 \\
\hline & 1 & 2 & 2 & 2 & 3 \\
\hline & 1 & 1 & 1 & 2 & 2 \\
\hline & 1 & 2 & 3 & 4 & 5 \\
\hline
\end{tabular}

Riskoccurrence probability $(\mathrm{x})$

The basis of risk assessment, quality and safety evaluation index can be carried out in two ways. One is based on relevant laws and regulations and quality and safety problems of wheat flour exposure by national standard sampling; others is based on the risk problems exposed by consumers or media.

Risk value of quality and safety evaluation index is calculated by formula (1). The weight of quality and safety evaluation index can be based on the ratio of the risk value of the quality safety index to the total risk value of the subordinate index. The calculation formula is:

The risk index value of the index weight $=\mathrm{Z} /$ the higher index total $\mathrm{Z}$ value $\mathrm{x} 100 \%$

According to the above calculation, the key control points in the flour quality safety control are obtained. We can targeted implement improved quality control measures.

\section{Exposure data analysis of wheat flour food hazards}

Analysis of national sampling results in recent 5 years. According to the requirements of the mandatory national standard GB1355-1986 "wheat flour" and GB2715-2005 " Hygienic standard of grain " .China makes sampling inspection for moisture content, ash content, sand content, fatty acid value, aflatoxin, lead, arsenic, cadmium, mercury, benzoyl peroxide, potassium bromate, titanium dioxide, sodium formate, magnetic metals, Escherichia coli, bacteria, labling and other items. Statistics of unqualified sampling results from 2010 to 2014 are shown in Table 2.

Table 2Statistical table of unqualified items

\begin{tabular}{|c|c|c|c|c|c|c|}
\hline $\begin{array}{l}\text { Unqualified items' number and } \\
\text { unqualified rate }\end{array}$ & $\begin{array}{l}2010 \\
(300)\end{array}$ & $\begin{array}{l}2011 \\
(120)\end{array}$ & $\begin{array}{l}2012 \\
(120)\end{array}$ & $\begin{array}{l}2013 \\
(150)\end{array}$ & $\begin{array}{l}2014 \\
(1941)\end{array}$ & Total \\
\hline Moisture & 4 & & & & & 4 \\
\hline Ash content & & $1(0.8 \%)$ & $2(1.6 \%)$ & & & 3 \\
\hline Sand content & 2 & & & & & 2 \\
\hline Benzoyl peroxide & $9(3 \%)$ & & & $2(1.3 \%)$ & $3(0.2 \%)$ & 11 \\
\hline Lable & & & & $1(0.7 \%)$ & & 1 \\
\hline Deoxynivalenol & & & & & $5(0.3 \%)$ & 5 \\
\hline Total & 15 & 1 & 2 & 3 & 8 & - \\
\hline
\end{tabular}


Table 1 shows that benzoyl peroxide occurs almost every year over the years, and the rate of disqualification is relatively high. In addition, moisture, sand content and other items are frequent quality problems of flour products.

Exposure analysis of wheat flour food based on consumer complaints and other analysis. Nutrient fortifier is the nutrient to recover the loss during the process of restoring wheat. ${ }^{[6]}$ The effect of nutrition fortifier is the standard of vitamins and minerals in flour, so vitamins, minerals and other content can be used as indicators of flour safety evaluation.

Media reports showed that in the 2014, the first imported wheat in Hainan port appeared "Southern three Jing", which was a very harmful weed. Because most areas in China are suitable growing areas, once introduced, it will have a serious impact on wheat production. So we regarde it as a potential risk in the flour safety evaluation index.

Physical hazards such as hard and soft materials are foreign sources enter the flour, which are due to improper operation or production equipment and working environment are not meet the requirements. It should be included in the regulatory indicators.

Flour packaging should generally consider the flour moisture, pest control and other issues, so there are some inevitably unsafe factors such as Polyethylene, polyvinyl chloride, etching packaging materials. These harmful substances are generally divided into three aspects: One is the basic packing material; two is the auxiliary agent that is converting basic packaging materials into packaging; three is the ink on the surface. Common migration of harmful substances includes antistatic agent, plasticizer, antioxidant, phthalate two formic acid, bisphenol A (BPA) and so on. Long term consumption will have great harm to liver. ${ }^{[7]}$ Packaging links are easily overlooked, but the harm of harmful substances in package is very serious.

Do analysis and evaluation according to the above national sampling data and other ways of exposure data, determine the content of flour risk evaluation index and then construct evaluation index system, such as the three level index system of Table 4.

\section{Risk Matrix Method to Determine Index Risk Grade}

Determination of Criteria for Risk Matrix. The criteria for determining the likelihood of a small wheat flour risk project through national sampling inspection results, consumer complaints, media exposure and expert opinions are shown in table 3.

Table 3Criteria for determining the possibility of occurrence of a food safety risk item $X_{i}$

\begin{tabular}{|l|l|l|}
\hline Level & Score & \multicolumn{1}{|c|}{ Level description } \\
\hline Frequently & 5 & $\begin{array}{l}\text { 1.Unqualified rate of sampling batch accounted for more than 4\% over the past year; } \\
\text { 2.Consumer complaints, media exposure and other ways show that the number of } \\
\text { risks more than 6 times. }\end{array}$ \\
\hline Usually & 4 & $\begin{array}{l}\text { 1. Unqualified rate of sampling batch accounted for more than 2\% over the past year; } \\
\text { 2. Consumer complaints, media exposure and other ways appear more than 4 times. }\end{array}$ \\
\hline Occasionally & 3 & $\begin{array}{l}\text { 1.Unqualified rate of sampling batch accounted for more than 1\% over the past year; } \\
\text { 2.Consumer complaints, media exposure and other ways appear more than 3 times. }\end{array}$ \\
\hline Rarely & 2 & $\begin{array}{l}\text { 1.Unqualified rate of sampling batch accounted for more than 0.1\% } \\
\text { 2. Consumer complaints, media exposure and other ways appear more than once. }\end{array}$ \\
\hline Never & 1 & $\begin{array}{l}\text { 1.National sampling inspection, the project is qualified; } \\
\text { 2.No media exposure, consumer complaints and other cases occurred. }\end{array}$ \\
\hline \multicolumn{2}{|l}{ The two conditions in the above level description satisfy one of the corresponding grades. } \\
\hline
\end{tabular}

By the relevant provisions of the state, the harm of human body produce, risk influence scope and special requirements for special groups and involves the severity degree evaluation risk, its criteria as shown in table 4. 
Table4The seriousness of food safety risk project $Y_{\mathrm{i}}$ grade criterion

\begin{tabular}{|l|c|l|}
\hline Level & Score & \multicolumn{1}{c|}{ Qualitative description } \\
\hline $\begin{array}{l}\text { Very } \\
\text { seriously }\end{array}$ & 5 & $\begin{array}{l}\text { 1.Once arises, the state takes coercive measures to ban the market circulation instantly; } \\
\text { 2.Leading to consumer death or group acute poisoning; } \\
\text { 3.The issue has aroused nationwide attention. }\end{array}$ \\
\hline $\begin{array}{l}\text { More } \\
\text { seriously }\end{array}$ & 4 & $\begin{array}{l}\text { 1.National or regional regulations strongly limit the content of flour; } \\
\text { 2.Causing consumers to not recover injury or cause minor poisoning in the group; } \\
\text { 3.Special attention has been paid to regional problems after the issue. }\end{array}$ \\
\hline Seriously & 3 & $\begin{array}{l}\text { 1.Once arise, the state formulates measures to strictly control the market circulation; } \\
\text { 2.Leading to moderate harm to consumers, medium and long-term recovery; } \\
\text { 3.Regional common concerns arise after the problem. }\end{array}$ \\
\hline Commonly & 2 & $\begin{array}{l}\text { 1. Once arise, the state takes appropriate measures to control the market circulation; } \\
\text { 2.Leading to mild harm to consumers, short-term recovery } \\
\text { 3. The attention is low after the problem. }\end{array}$ \\
\hline Not serious & 1 & \begin{tabular}{l} 
No harm was found and no attention was paid to it. \\
\hline Scores when satisfying one of the conditions in the above level description.
\end{tabular} \\
\hline
\end{tabular}

Risk grade evaluation. By formula (1) to determine the wheat flour quality and safety level of risk evaluation indexes, through the formula (2) it is concluded that the weights are adjacent supervisor as shown in table 5 .

Table 5 Flour risk assessment

\begin{tabular}{|c|c|c|c|c|c|c|c|c|c|}
\hline & $\begin{array}{l}\text { Level } 1 \\
\text { indicators }\end{array}$ & $\begin{array}{l}\text { Level } 2 \\
\text { indicators }\end{array}$ & $\begin{array}{l}\text { Level } 3 \\
\text { indicators }\end{array}$ & $\begin{array}{l}\text { Weig } \\
\mathrm{ht}[\%]\end{array}$ & $\begin{array}{l}\text { Risk project } \\
\text { segmentation }\end{array}$ & $X$ & $\mathrm{Y}$ & $\mathrm{Z}$ & $\begin{array}{l}\text { Level of } \\
\text { risk }\end{array}$ \\
\hline & \multirow{9}{*}{$\begin{array}{c}\text { Food } \\
\text { hygiene } \\
\text { index }(53 \\
\%)\end{array}$} & \multirow{2}{*}{$\begin{array}{c}\text { Biological } \\
\text { pollution }(12 \%)\end{array}$} & $\begin{array}{l}\text { 1.Total bacterial } \\
\text { count }\end{array}$ & $53 \%$ & $\begin{array}{l}\text { Yeast, bacillus, } \\
\text { coliform bacteria, }\end{array}$ & 3 & 5 & 4.3 & Veryhigh \\
\hline & & & $\begin{array}{l}\text { 2.Three fruits of } \\
\text { South China }\end{array}$ & $47 \%$ & $\begin{array}{l}\text { Three fruits of South } \\
\text { China }\end{array}$ & 1 & 5 & 3.8 & high \\
\hline & & \multirow{5}{*}{$\begin{array}{c}\text { Chemical } \\
\text { pollution }(35 \%)\end{array}$} & 3. Natural toxin & $17 \%$ & Aflatoxin B1,DON & 4 & 4 & 4 & high \\
\hline & & & \multirow{2}{*}{ 4.Food additives } & \multirow{2}{*}{$43 \%$} & Benzoyl peroxide & 5 & 5 & 5 & very high \\
\hline & & & & & Potassium bromate & 5 & 5 & 5 & very high \\
\hline & & & 5.Heavy metal & $20 \%$ & $\mathrm{Hg}, \mathrm{Cr}, \mathrm{C}$ & 4 & 5 & 4.6 & very high \\
\hline $\mathrm{A}$ & & & $\begin{array}{l}\text { 6.Pesticide } \\
\text { residue }\end{array}$ & $20 \%$ & $\begin{array}{l}\text { CCC, Paraquat, } \\
\text { Chlorothalonil }\end{array}$ & 4 & 5 & 4.6 & very high \\
\hline s & & \multirow{2}{*}{$\begin{array}{c}\text { Physical } \\
\text { pollution (7\%) }\end{array}$} & \multirow{2}{*}{$\begin{array}{l}\text { 7.Soft and hard } \\
\text { objects }\end{array}$} & $50 \%$ & Glass, Sand, Wire & 2 & 2 & 2 & low \\
\hline s & & & & $50 \%$ & Hair, worms & 2 & 2 & 2 & low \\
\hline $\begin{array}{l}\text { e } \\
\text { s }\end{array}$ & \multirow{8}{*}{$\begin{array}{c}\text { Balanced } \\
\text { diet } \\
\text { index }(31 \\
\%)\end{array}$} & \multirow{3}{*}{$\begin{array}{l}\text { Basic nutrition } \\
\qquad(13 \%)\end{array}$} & 8.Protein & $38 \%$ & Content substandard & 2 & 4 & 3.3 & medium \\
\hline $\begin{array}{l}S \\
s\end{array}$ & & & 9.Lipid content & $31 \%$ & Content substandard & 2 & 3 & 2.6 & medium \\
\hline $\begin{array}{l}\mathrm{s} \\
\mathrm{m}\end{array}$ & & & 10.Carbohydrate & $31 \%$ & Content substandard & 2 & 3 & 2.6 & medium \\
\hline 1 & & \multirow{3}{*}{$\begin{array}{c}\text { Adjust } \\
\text { nutritional } \\
(12 \%)\end{array}$} & 11.Moisture & $36 \%$ & Content substandard & 3 & 3 & 3 & medium \\
\hline $\mathrm{n}$ & & & 12. Vitamine & $32 \%$ & Content substandard & 2 & 3 & 2.6 & medium \\
\hline $\mathrm{t}$ & & & 13.Mineral & $32 \%$ & Content substandard & 2 & 3 & 2.6 & medium \\
\hline & & \multirow{2}{*}{ rests $(8 \%)$} & 14.Ash content & $54 \%$ & Content substandard & 3 & 3 & 3 & medium \\
\hline i & & & 15.Fatty acid & $45 \%$ & Content substandard & 2 & 3 & 2.6 & medium \\
\hline \multirow{3}{*}{$\begin{array}{l}\mathrm{n} \\
\mathrm{d} \\
\mathrm{e} \\
\mathrm{x}\end{array}$} & \multirow{3}{*}{ rests $(16 \%)$} & Package (5\%) & $\begin{array}{l}\text { 16.Harmful } \\
\text { substances }\end{array}$ & - & BPA & 2 & 4 & 3.3 & high \\
\hline & & \multirow{2}{*}{ Lable(8\%) } & 17.Content & $50 \%$ & $\begin{array}{c}\text { Vague,incomplete, inc } \\
\text { onsistent }\end{array}$ & 2 & 3 & 2.6 & medium \\
\hline & & & 19.False label & $50 \%$ & $\begin{array}{l}\text { Adulterate;Fraudulent } \\
\text { use of famous brands }\end{array}$ & 2 & 3 & 2.6 & medium \\
\hline
\end{tabular}

The Formulation of Countermeasures. According to the level of risk decision and the reality of the government regulation, formulating targeted response as shown in table 6.Take targeted supervision to reduce the risk level by distributing regulatory forces reasonably. According to the result of each regulation and complaint, adjust index risk level, realize the dynamic adjustment of 
regulatory plan.

Table 6 Table of response measures

\begin{tabular}{|c|c|l|}
\hline $\mathrm{z}$ & Risk Level & \multicolumn{1}{|c|}{ Response } \\
\hline$(4,5]$ & very high & $\begin{array}{l}\text { 1.Thegovernment investigatethe causes of the problem and the production } \\
\text { processimmediately;2.The inspection department increase the sampling frequency50\% } \\
\text { and make contingency plans;3.Supervise enterprises to identify and establish key } \\
\text { control points and take preventive measures to eliminate risks. }\end{array}$ \\
\hline$(3,4]$ & high & $\begin{array}{l}\text { 1.The governmentinvestigate the causes of the problem and the production process } \\
\text { immediately;2.The testing department increase the sampling frequency 30\%and make } \\
\text { contingency plans;3.Supervise enterprises to establish and establish key control points } \\
\text { and take precautions measures to eliminate risks. }\end{array}$ \\
\hline$(2,3]$ & medium & $\begin{array}{l}\text { 1.The governmentinvestigate the causes of the problem and the production process } \\
\text { 2.The testing department increase sampling frequency 10\%;3.Supervise the enterprise } \\
\text { to establish the key control points, take precautions measures to eliminate the risks. }\end{array}$ \\
\hline$[1,2]$ & low & \begin{tabular}{l} 
Appropriate sampling frequency can be relaxed for projects with low risk level. \\
\hline
\end{tabular}
\end{tabular}

\section{Summary}

In this paper, the risk assessment model and the improvement measures wereput forward by food safety exposure, which could provide reference for food safety risk assessment research and wheat flour quality supervision. Since the quantitative analysis combined with the expert evaluation opinion has subjectivity, the risk grade can be timely evaluated and dynamically adjusted according to the regulatory situation and the changes after implementation.

\section{Acknowledgements}

Project supported by the Hebei University innovation and entrepreneurship training program (national level 201710075023).

\section{Reference}

[1] Z.X.Liu and M.Liu :Journal of Huazhong Agricultural University,Vol.06(2015).No.34,p.73.(In Chinese)

[2] J.Lei, X.M.Li,Y.B.Liang and M.Q.Zhao :Food research anddevelopment,Vol.35(2014),p.126.

[3] L.X.Liao,J.X.Wang :InspectionandQuarantineScience,Vol.06(2013),p.63.(In Chinese)

[4] Y.Wang and X.Zhao :Tianjin Agricultural Science Daily,Vol.5(2014),p.47.(In Chinese)

[5] Q.Haoand R.X.Su :Food science report,Vol.21(2014),p.279.(In Chinese)

[6] Suzanne J.P.L. van den Berg, Verena Klaus, Wasma Alhusainy, and IvonneM.C.M. Rietjens, Matrix-derived combination effect and risk assessment for estragole from basil-containing plant food Supplements (PFS), Food and Chemical Toxicology, Vol.62, 2013

[7] Y.D.Lu and J.F.Zhao:Grain Processing,Vol.04(2017),p.25.(In Chinese)

[8] G.H.Liu : Grain Processing,Vol.05(2017).No.42,p.8.(In Chinese)

[9] X.X.Gao,H.Ye and Y.B.Kang:Science and Technology Management Research, Vol.13(2014) ,p.8. (In Chinese)

[10] X.Y.Hu,L.Y.Lin,W.J.Tang and Z.X.Li:Systems Engineering-theory \& Practice, Vol.34(2014). No.5,p.1213.(In Chinese)

[11] Y.S.Duan,J.G.Zhao,P.Chen and B.L.Zhao:China Safety Science Journal,Vol.27(2017).No.2, p70.(In Chinese) 